\title{
Chapter 3 \\ Japanese Images of the Jews: Myths, Canards and Fears
}

We have noted the almost total absence of any Jewish influence on Japanese politics, culture, media, and academia, even in the three communities where the Jewish population concentrated-Nagasaki, Yokohama, and Kobe. However, it can be safely assumed that the strange religious practices of the Jews aroused some interest among Japanese people, who may have wondered about the differences between Christian churches and Jewish synagogues, special "kosher" food for Jews, special burial sites, and their practice of attaching mezuzot to the doors of their homes and even kissing them. Some may have noted that during prayers Jews wore prayer shawls and skull-caps and prayed towards the West in the direction of Jerusalem. To the extent that some Japanese people wondered about these practices and rituals, however, their general sense was that Judaism was just another Christian sect, albeit one with its own rituals, and therefore no special attention was devoted to them.

\section{The Japanese as Descendants of the Ten Lost Tribes}

Over the course of the second half of the nineteenth century, several members of the new Japanese intellectual elite became interested in the Jews and their history. This was due mainly to the increasing number of Jewish settlers and to the appearance of works by European writers who studied the origins of the Japanese people and occasionally likened those origins to Jewish history. One of these publications appeared in Nagasaki in 1879, and was called Japan and the Lost Tribes of Israel. ${ }^{1}$ The book's author, Norman McCleod, was a British businessman of Scottish descent who had lived in Japan since 1867. He claimed that on the basis of his research there were many similarities between Japanese and Jewish culture. Shinto temples, he argued, were similar to ancient Jewish temples, and some Shinto rituals 
reminded him of Jews parading with Torah scrolls in their synagogues. On the basis of his evidence, he came to the conclusion that the Japanese people were descended from the ten lost tribes of Israel, who reached Japan after they crossed the Asian continent and captured China and Korea, where they established a Jewish kingdom. This, of course, had no bearing on reality, as has been shown repeatedly since then.

Strange as it may seem, interest in the bizarre theory that the Japanese were the descendants of the ten lost tribes was due to the growing influence of the Christian Western powers in Japan and their ability to dictate to that weak nation a set of unequal treaties which forced Japan to open its gates to trade and settlements of foreigners. Many Japanese people began to wonder about the roots of Western power and wondered whether there was a connection between Christianity and the building of an overseas empire. Two noted Christian Japanese scholars, Oyabe Zenichiro (1868-1941) and Sakai Katsutoki (1874-1940), studied theology in the United States, where they were ordained. They too claimed that there was a connection between Japan and the ancient Jews. After abandoning Christianity at the ends of their respective lives, the two argued that Holy Japan must be the spiritual leader of the universe and that the Japanese imperial family was the embodiment of the Messiah. They also wrote that the Japanese are the legitimate heirs of the ancient Jews and derive their heritage from those ancient Jews, rather than from the Jews of modern times. ${ }^{2}$ These two scholars eventually supported radical Japanese nationalism in the 1930's and the early 1940's. In this bizarre manner, the connection between modern Japan and ancient Judaism became a political tool that served Japanese nationalism and militarism in the 1930's. It was also designed to showcase Japan as the repository of an ancient history at least as old as Jewish history, and thus was a tool to be used as an argument against some Western scholars who claimed that Japan was-unlike China - a relatively new country.

In 1980, an Israeli researcher and writer, Joseph Eidelberg, published a book called The Japanese and the Ten Lost Tribes of Israel, in which he examined most of the Japanese publications on this subject and proposed the existence of a Japan-Jewish connection dating to the seventh century. In it, he claims that the word Yamato, the center of ancient Japan, is similar to Yehoamato-the people of God. He argues that the ancient Japanese began their journey in history in a year called Kinoye Tora, which he connected with the Hebrew words Kenei Torah (Torah reeds). The title "Agata Noshi," awarded by a Japanese emperor to his nobles, was identified by Eidelberg 
as close to "Aguda Nassi", or "Nessi Aguda" (meaning "chairman of the association"). All this sounds far-fetched and not plausible, although it is certainly interesting. ${ }^{3}$

\section{Russian Antisemitism and the Japanese}

In the absence of a sizeable and influential Jewish community in Japan, it seems likely that if there was a growing Japanese interest in Jews and a growing preoccupation with the image of the Jews, these were primarily the result of Russo-Japanese contacts and the evolution of a complex relationship that developed between the two peoples in the first two decades of the twentieth century.

The first Japanese scholar who sought to understand the meaning of the so-called "Jewish Question" in Europe was Kamuyama Sentaro (18771954). In May and June of 1905, he published a series of articles in the highly respected and influential magazine Chuo Koron called "Antisemitism and Zionism." In it, he argued that the Jews were a persecuted minority in Russia, that the Tsarist regime of that empire was inciting the masses to undertake pogroms against them, and that among the Jews there had developed a national movement called Zionism. He was probably drawn to this field because of the growing interest in Jews, and particularly in Jewish financial power, during the Russo-Japanese War. ${ }^{4}$

The first phase in the introduction of antisemitism to Japan took place in the years immediately following the October 1917 Bolshevik Revolution in Russia, the toppling of the Tsarist regime, and the occupation of parts of Siberia by Japanese forces starting in 1918. The Bolshevik revolution came as a huge shock to Japan. During the First World War, Russia and Japan were fighting on the same side against the Central powers and signed a number of agreements, dealing mainly with Japan's war-time aspirations in China, which were embodied in the 1915 Twenty-One Demands. The 1917 Russian Revolution created a huge void in the Far East that aroused hopes among some senior Japanese military officers that their country could profit by it. However, it also heightened fears of what could happen in the region now that Russia had become the Soviet Union and the Tsar and his entire family had been executed.

Into this complex situation the Jews were drawn, indirectly and for various and at times opposing reasons. They were seen as the most visible national element among the makers of the Bolshevik revolution, and thus as directly involved and perhaps even responsible for the murder of the 
Tsar. The brutal elimination of the autocratic Tsar and the entire imperial family in early 1918 stunned many in Japan and was seen as regicide. This execution, it was feared, could serve as a model for the elimination of the Japanese imperial family, which was at the heart of the Japanese Kokutai (national essence). ${ }^{5}$

Additional military and political developments in the Russian Far East were even more important and urgent than these concerns. To the collapse of the Tsarist regime and the withdrawal of the Soviet Union from the war there was added the fear that the newly-created Soviet Union would seek to avenge Russia's defeat by Japan in their recent war, barely thirteen years in the past. There was a great deal of discussion in Japan, as well as in the United States and the countries of Western Europe, of the "Red Peril," a phrase reminiscent of what was once called the "Yellow Peril."

Beginning in January 1918, when Lenin signed the treaty of BrestLitovsk, resulting in, among other things, the withdrawal of Russia from the war against the Central powers, the Allied powers were determined to keep Russia in the war at least in Asia. One reason for this goal was so that the 60,000 men of the so-called "Czech Legion," consisting of Czech prisoners of war held by Russia, could escape from Russia via East Asia back to Europe to help the Allies fight Germany. This was the main reason given to justify the decision to land British and American troops in Vladivostok (in addition to other sites in European Russia). These troops arrived in early August 1918, and Japan was invited to participate in the expeditionary force. In the Japanese leadership there were arguments not over the principle of participating in this venture, but over the goals, the scope, and the dimensions of the intervention, how many troops should be committed to Siberia, how far they should advance, and how long they should remain there.

Some in Japan supported the intervention in order to gain control of the Trans-Siberian Railway. Among these was the Russian director-general of the Chinese Eastern Railway, Piotr Horvat. Through its participation, he argued, Japan's position in Manchuria would be strengthened. General Tanaka Giichi (1864-1929), who would become Japan's prime minister in 1927 , along with some of his colleagues, including generals and admirals as well as other senior Japanese army and navy officers, began to dream about the creation of a Japanese Asian empire extending all the way to Lake Baikal. Japan finally decided to send troops, double the the number that the Allies had initially requested. Officially, this move was made in concert with the United States, Britain, France, and Canada, and was designed to protect the 
interests of the Western powers after the overthrow of the Tsarist regime and the murder of Nicholas II. At the height of its presence, the Japanese expeditionary force numbered some 72,000 soldiers. But even this large force was unable to stem the advance of the Red Army toward Vladivostok, the main base of the Japanese army. In this port city, and in some surrounding Siberian towns, there remained "White" Russian forces-forces loyal to the old regime-under the overall command of Admiral Alexander Vasilyevich Kolchak (1874-1920) and his chief local commander, General Grigori Semyonov (1890-1946), who planned to establish an anti-Bolshevik government in Siberia. After the end of the war in Europe, the Western Allies withdrew their forces from Siberia, asking Japan to do the same, but Japan's government prevaricated and the force remained in place until 1922. By then it was becoming obvious that Japan's adventure in Siberia was unfruitful, as it had cost a fortune and had not achieved any significant political, territorial, or economic gains. ${ }^{6}$

\section{The Protocols of the Elders of Zion?}

Over the course of the almost four years of Japanese military presence in Siberia, Japanese officers were exposed to the White Russians' searing hatred for the Bolsheviks and also their animosity toward the Jews, whom they accused of being the main culprits responsible for the Bolshevik Revolution and the total collapse of the ancient order in Russia, as well as the execution of the imperial family. It was the White Russian officers who supplied Japanese expeditionary force officers with antisemitic tracts, most notably the Protocols of the Elders of Zion.

The origins of this document are murky, despite the fact that in recent years its history has been thoroughly researched. The text itself is an uncredited and altered copy of a book that was initially published in France during the reign of Napoleon III and contained material that ascribed dangerous intentions to Napoleon. The book was translated to Russian by the Russian secret police, the Okhrana, and after pertinent adaptations it was released to explain to the Russian people that the Jews were responsible for all the ailments that beset Russian society, including its defeat in the RussoJapanese war. The aim was to prove that many of Russia's problems were the consequences of an international Jewish plot to destroy the Russian state. The core of the story is a series of twenty-four lectures delivered in the old Jewish cemetery in Prague by a figure referred to as the Chief Rabbi, whose audience consists of the representatives of the twelve tribes of Israel-the 
Elders of Zion. This group is ostensibly a secret Jewish government that plans to destroy and then take over no less than the entire Christian world.

This document first appeared in Russia in 1905 as an annex to the Russian mystic Sergei Nilus' (1862-1929) book The Great in the Small: The Coming of Anti-Christ and the Rule of Satan on Earth. A further edition of Nilus's book appeared in 1917, and was called, "It's Close to Our Doors." The connection between the Jews and their influence on the Bolshevik Revolution was clear. That Revolution was seen as the direct result of a plot concocted by world Jewry, meant to first destroy the Russian empire and then take over the entire Christian world and kill its leaders, starting with the Tsar. The tract in fact absolved the heads of the Tsarist government from all blame, because they never had a chance to resist this horrific Jewish plot. The presence of so many Jews among the leaders of the Bolsheviks and in the new Soviet leadership only supported the claim that the Revolution was a key part of a Jewish scheme.

The Protocols of the Elders of Zion was distributed in large numbers among White Russian soldiers and officers, and received a great deal of interest and credence. After Russian military personnel in Siberia shared the tract with their Japanese counterparts between 1918 and 1922, copies of it found their way to Japan, where excerpts were published in 1920 in a series of articles called "The Jewish Peril" in the publication Shinrei.

Some scholars wonder to this day about the secret of the success of an untruthful antisemitic document in Japan, a country which had barely a thousand Jewish residents and no antisemitic tradition, where Jews had never been suspected of threatening the state, its culture, or its religion. The circulation of the Protocols in Japan, in fact, increased Japanese interest in Jews and Judaism. Some Japanese scholars wondered how the Bolsheviks, theoretically controlled by Jews, were able to take over the vast Russian empire so rapidly. Furthermore, it was thought, if indeed the Jews controlled the international economy and held enormous influence over the governments of the major powers, perhaps it was time that more Japanese should learn more about them. The reaction reads like a combination of the Red Scare and the Jewish Peril. ${ }^{8}$

Another reason for the growing interest in the Protocols was the development of severe domestic Japanese problems at the end of the First World War. After years of economic prosperity caused by the war, during which Japan had supplied the Allies and other countries with goods and services, Japan's economy stagnated, leading to rioting in Tokyo and other Japanese cities. These outbursts, known as the "Rice Riots" of 1919, were 
seen as an expression of the growing dissatisfaction of the Japanese people with the spiraling rise of the price of basic commodities. Some Japanese leaders, mainly the more conservative among them, felt that the unrest was influenced by the new doctrines of socialism, communism, and even anarchism emanating from Russia. The doctrines were initiated by Jews, they argued, who played key roles in the development and expansion of communist doctrines, starting with Karl Marx (1818-1883) and ending with the new rulers of Communist Russia-Leon Trotsky (1879-1940), Lev Kamenev (1883-1936), Grigory Zinoviev (1883-1936), and Karl Radek (1885-1939), to name a few. They knew that in various other European countries Jews stood out as leaders of communist uprisings, such as Rosa Luxemburg (1871-1919) and Karl Liebknecht (1871-1919) in Germany and Bela Kuhn (1886-1938) in Hungary. Thus, Jews were seen as leading an international revolutionary movement that was spreading its tentacles in many countries. Fear spread among some Japanese leaders that there would be growing demands in Japan for greater democracy and civil rights, something that could endanger their rule, the spirit of the Kokutai the national essence and structure - undermine Japan's social makeup, and lead to anarchy. Naturally, Jews were accused of spreading such ideas as democracy, equality, and progress. A group of Japanese leaders, among them Prince Konoe Fumimaro (1891-1945), future prime minister and scion of an ancient aristocratic family, were in Paris in 1919 for the Peace Conference. In a series of articles written from Paris, Konoe complained that Japan was being humiliated by the Western powers, who were determined to preserve their colonial and imperial standing in their Asian and African holdings while demanding of Japan that it give up its claims to parts of China, mainly in the Shandong Province, and renounce the 21 demands it had presented to China in $1915 .{ }^{9}$ Konoe and others in the Japanese ruling elite and the military high command saw the West as a clear threat to Japan's aspirations on the Asian continent. These elites, who still bore the legacy of the oligarchy of the late Meiji period, feared that the social unrest in Japan was partly due to new Western ideas imported from the West and from Russia: socialism, liberalism, democracy, communism, anarchism, and the desire for a pluralistic and secular society. Some of them identified Jews with the Western regimes because of their perceived influence on their social and economic policies. Thus, Jews were identified with those in the West who were determined to undermine the Japanese social and political structure and also prevent them from taking what they considered their rightful place in Asia. 
After Konoe committed suicide in December 1945 and his journals were published, it emerged that his antisemitism was mainly due to fear of Bolshevism and the fact that he considered Marxism a "Jewish disease." In this respect he was similar to a large number of influential Germans who claimed that their country was defeated in the First World War by a "stab in the back" from its Jewish population. As evidence of Jewish might and influence, these Germans cited the April 1922 Rapallo Friendship Treaty, signed between the Soviet Union and Germany, which created the military cooperation that helped build the Red Army. They noted that this treaty was signed by German Foreign Minister Walther Rathenau (1867-1922), a German Jew, and on the Soviet side by Foreign Minister Grigori Chicherin (1872-1936), a non-Jew. Here was additional proof that a Jewish foreign minister ran the affairs of a major power. Senior Japanese staff officers feared the growing strength of the Red Army created and initially led by Leon Trotsky (born Lev Bronshtein). It was easy to conclude that influential Jews in the West and certainly in the Soviet Union had joined together to keep Japan as a second- or even third-rate power.

Herein, however, lies the paradox. On the one hand there existed among the Japanese ruling elites a keen interest, verging on admiration, for Jews, who they saw as possessing vast amounts of influence over various governments. They thought of them as the clever, intelligent, crafty Jews with special talents mainly in finance and international politics. This was another Western "contribution" to Japan: in the West as well, Jews were seen at best as possessing vast powers far exceeding their numerical strength. Some key Japanese leaders also considered them highly influential and well-placed in strategic positions. Many Japanese civilian and military leaders knew well the action undertaken by Jacob Schiff and his associates to rescue Japan from financial ruin during the Russo-Japanese War. Some also expressed fear that American and European Jewish bankers might help shore up the Soviet Union in revenge for the pogroms carried out during the era of the Tsarist regime. There was anxiety that major Jewish financial concerns run by Jacob Schiff, Felix Warburg (1871-1937), and the Lehman, Goldman, and Sachs families would underwrite or even guarantee loans taken out by the new communist government of Russia. Such fears were encouraged by White Russian soldiers and officers in Siberia, who made sure these ideas would be passed on to Japanese forces in Siberia during the era of Japanese presence in that part of Russia.

Not everyone in Japan was convinced that the Protocols was a genuine document. As early as 1921, after it was translated into English and found 
its way to Japan in that language, there were some who argued that the historic foundation of the text is basically false. One of these skeptics was Yoshino Sakuzo (1878-1933), a respected law professor at Tokyo University, who wrote two articles on the subject in the magazine Chuo Koron in MayJune 1921. In them, he argued that there was no basis for the assumption of an international Jewish plot, and that the distribution of the Protocols in the West was an opaque attempt to blacken the name of the Soviet Union by attacking the Jews who held central positions in the newly created Soviet government. ${ }^{10}$

As was mentioned above, the Protocols was first translated into Japanese in 1920, and excerpts appeared in a series of articles in Shinrei called "The Jewish Peril,” written by Higuchi Tsuyanosuke (1870-1931). Higuchi attended a Russian Orthodox Seminary in Tokyo, and was later ordained as an Orthodox priest by the Theological Seminary in St. Petersburg, Russia. It is likely that during his studies in Russia he became imbued with antisemitic ideas. Since he was fluent in Russian, he was attached to the headquarters of the Japanese forces in Siberia as a Russian affairs specialist and served there for three years as an interpreter. The entire Protocols of the Elders of Zion was later translated to Japanese by Major (later Colonel) Yasue Norihiro (1881-1950), who was at the time serving in the headquarters of the fifth Japanese Army in Siberia, attached to the headquarters of the White Russian General Grigory Semyonov. ${ }^{11}$ He translated 120 pages of text and wrote an eighty-page introduction, under the pseudonym Ho Koshi. He called the combined text The Seamy Side of the World Revolution. He ignored the fact that in 1921 it was already generally understood that the Protocols were a forgery and lacked any historic or factual basis or validity. He was convinced that it was genuine. Yasue had been sent by the Japanese army to study Russian in the Foreign Languages School in Tokyo when the army had decided to train a number of Japanese officers in foreign languages. Incidentally, another student of Russian there at the time was a Japanese civilian named Sugihara Chiune (1900-1986), who later heroically provided thousands of Polish and Lithuanian Jews with documentation they needed to escape the Nazis. Perhaps it was during his Russian language studies that Yasue began to show an interest in the Jews.

Two other Japanese officers also played an important role in disseminating antisemitic tracts. One was the naval officer Captain Inuzuka Koreshige (1890-1965), ${ }^{12}$ and the other an infantry officer, General Shioden Nobutaka (1897-1962). ${ }^{13}$ The latter became the most outspoken and wellknown antisemite in Japan during the twentieth century. They, along with 
Yasue, were staff officers under the command of Major General Higuchi Kiichiro (1888-1970), and as part of their work as liaison officers to the Semyonov headquarters they read antisemitic publications in Russian. They may also have been influenced by antisemitic ideologies they learned from Semyonov and his soldiers. They began to use terms such as "Jewish Peril" and discuss the need to undertake severe measures before the Jews took over the entire world through means of revolutions, murder, and mainly by subverting, undermining, degenerating, and atrophying the cultures of the West and Japan.

Later in the 1920's, antisemitic publications entered Japan from other sources. One, translated into Japanese in 1927, was Henry Ford's The International Jew, which contained segments of the Protocols. Ford (18631947) had been publishing antisemitic articles since the early 1920s, mainly in local publications in Michigan that included citations from the Protocols. His fear of Jews derived from, among other things, the role they had played in setting up trade unions in America and in demanding unionization of the automotive industry in order to protect workers' rights. He saw unionization as a Jewish plot-hence his antisemitism. The publication of Ford's book in 1927 may have been seen by some Japanese people as giving them a green light for antisemitism. If the American tycoon Ford was allowed to publish such tracts in democratic and liberal America, they may have thought, then why couldn't Japan, at the time also struggling against the rise of trade unions and fearing strikes in essential services, adopt his stance against the Jews? The problem, of course, was that, unlike in Europe or the United States, there were no Jews involved in the creation of the Japanese trade union movement. Only after Japan's defeat in the Second World War did Jews become involved, in the capacity of some of General MacArthur's (1880-1964) senior political advisers during the occupation of Japan. Among this group were at least two Jewish advisers who suggested that the American occupation authorities immediately release imprisoned trade union leaders and permit the creation of trade unions in Japan. MacArthur agreed.

A further source for the spread of the antisemitic theories of the Russian school were the thousands of non-Jewish White Russian refugees who escaped from Communist Russia after the revolution and found shelter in some of the major cities of Manchuria, chiefly in Harbin, and in Tianjin and Shanghai in China. Few arrived in Japan proper. The refugees had a burning hatred for anything that smacked of communism due to the loss of their way of life, property, homes, and-above all, since they were 
Russian patriots-their homeland and their adored Tsar. For their survival these refugees, embittered and resentful, found themselves dependent on the good will of others. In the major cities of Manchuria they saw flourishing Jewish communities, including some very wealthy Jews, and contrasted them to their own destitute community. This only added to their anger and antisemitic feelings.

The combination of the White Russian forces of Kolchak and Semyonov, and the few Japanese staff officers who became interested in the "Jewish problem," proved to be pernicious, although anti-Jewish sentiment in Japan never reached the destructive dimensions of the antisemitism of Nazi Germany.

\section{New Political, Social, and Economic Reality-and the Long Arm of the Jews}

Another cause for the rise of interest in Jews and the growing antisemitism in Japan were the unexpected domestic developments in that country after the First World War. These years witnessed an ongoing struggle between those who demanded growing liberalization, democracy, and greater freedom in Japan and those who opposed these demands, between those who wanted to see Japan pursue a foreign policy based on international cooperation with the Western powers under the leadership of the League of Nations and those who argued that the West was determined to prevent Japan from attaining its rightful place under the sun and to prevent it from gaining any footholds anywhere on the Asian continent. Some Japanese politicians and senior army officers watched with growing concern the close ties that began to develop between the Chinese nationalist party, Chiang Kai-Shek's (1887-1975) Kuomintang, and the Soviet Union through the Comintern (Communist International), which sent to China a number of political advisers, military experts, and revolutionary ideologists. Among these emissaries were a number of Jews, including Adolph Yoffe (1883-1927), Lev (Leo) Karachan (1869-1937), and Michail Borodin-Gruzenberg (1884-1952). The combination of Chinese nationalism and Soviet Bolshevism was enough to alarm those in Japan who aspired for an active imperial role for Japan on the Asian continent in general, and on the Chinese mainland in particular.

An additional struggle was taking place in Japan between those who wanted to open the country to modern Western culture and those 
conservatives who feared for the impact of these ideas on Japanese youth. Among those who were determined to reconstruct what they considered to be sacred Japanese values and traditions was Kitta Ikki (1883-1937), who in 1919 wrote a book titled General Structure for the Reconstruction of Japan. This book had a vast influence on young Japanese officers, who were trained to worship the emperor and the homeland and to defend them against all enemies from within and without. ${ }^{14}$

No wonder, then, that at a time of growing restlessness, severe economic problems, a devastating earthquake that almost destroyed Tokyo and Yokohama in 1923, and the failure of the government to take immediate relief actions after it, many Japanese people sought culprits for their country's predicament. Japan was struggling with labor disputes and strikes, a steep rise in the price of food and other essential commodities, a growing social gap, and a constant struggle between conservatives and radicals, and all this contributed to the rise of the type of ultra-nationalist elements who normally flourish at such times. Part of the blame was aimed at foreigners in general, those from the West and in particular the Jews, although most Japanese people had still never laid eyes on a Jew. The antisemitic publications of the 1920's had been read mainly by a few individuals in the higher echelons of the Japanese army: they never filtered down to the general public and the Japanese masses. Most of the Japanese population was still agrarian, and the peasants certainly had never seen a Jew. Unlike in Europe, where certain social phenomena encouraged hatred of Jews, in Japan there was no phenomenon of the Jewish landlord, loan shark, trade union activist and organizer, editor or journalist, banker, industrialist, or political activist, and certainly there were no Jewish academics. There was nothing in Shintoism or Buddhism that was remotely anti-Jewish.

It was previously noted that one of the few Jews to have taught in a Japanese university up to that point was the German Jew Professor Ludwig Riess, who lectured at Tokyo University from 1887 to 1902. Riess was a student of the leading historian Leopold von Ranke (1795-1886), and went to Japan because he was unable to secure a teaching position in Germany. He was also the guiding spirit of the journal of the Association for the Study of History in Japan. While it is true that he was well known, he was considered by Japanese society to be a German, and his Jewishness was overlooked. ${ }^{15}$

Unlike in other countries, there were no Jewish writers, musicians, playwrights, film makers, doctors, lawyers, or accountants in Japan of this period. Jews did not pursue these occupations mainly because most of them did not know the language well enough to communicate with prospective 
clients and made no effort to learn Japanese. Few thought of Japan as their permanent homeland, many seeing it instead as a way-station to Western Europe, or preferably America. Jews never served in the Imperial Japanese army or navy. They were mainly agents of foreign companies. They barely had communal institutions, and did not have their own Jewish school system - their children attended international schools, some of them run by Christian missionaries. There was almost no intermarriage with the native Japanese populations. They spoke the languages of their countries of origin. Few joined the Zionist movement, and none are known to have been suspected by the Japanese police of un-Japanese activities or disloyalty to the country.

The 1920's were a period of growth and relative security for many Jewish communities in Europe. Thus, few Jews wanted to relocate to foreign countries. Those who wanted to immigrate to Palestine had no difficulty doing so, as the gates of that country were open at the time. The only country that did not allow Jews to emigrate was the Soviet Union. This meant that in the 1920's, Japan was not experiencing a major and urgent Jewish refugee problem.

In 1924, the United States closed its doors to migration from Eastern Europe, affecting predominantly Jews. The few thousand Jews who decided to resettle in East Asia generally preferred at first Harbin, and later Shanghai, where there were already prosperous Jewish communities with health, welfare, educational, and religious institutions and facilities, where Jews spoke German, Russian, and English, and above all, where the Jewish community members were ready to help in the absorption of new arrivals. In Japan, apart from Kobe, there were no such hospitable Jewish communities, and the Japanese government did not make it easy for foreigners to enter its territory. Part of the new difficulty was due to Japan's reaction to the draconian American immigration law of 1924, which allowed an annual quota of only several hundred immigrants from Japan. This was seen in Japan as a major national insult based on race, and Japan responded by effectively closing its gates to foreigners, a policy that in fact remains informally in force until today. Those who were hurt by the new American immigration laws were mostly European Jews who sought shelter in the United States after the rise of Hitler in 1933.

Why was there such a positive echo in some Japanese quarters to antisemitic theories? Part of the answer lies in the failure of the Japanese intervention in Siberia and the Western demand that Japan renounce its claims to Shandong. Another part is the general ignorance most Japanese 
people had at the time of the history of foreign nations. Although the school curriculum in Japan did include the study of Western countries, some of what they learned was tainted with anti-Western contents that stressed the uniqueness of Japan and the superiority of the Japanese race under the emperor-who was seen as superior to other dynasts, and who would implement Japan's destiny to purge Asia of Western presence and influence. As Japan failed to cope properly with the world economic crisis that began on Wall Street in October 1929, there was a growing need to seek someone who could be blamed for its plight.

As there developed among conservative intellectuals and the middle class a growing fear of the Western materialistic lifestyle and of Western influence and capitalism, some tended to connect these forces with Jews and consider both the antithesis to the spirit of Japan. Antisemitism in Japan in the 1920's can also be interpreted as a part of the era's general anti-cosmopolitanism and support for traditional Japanese culture, values, and way of life. Perhaps Jews were also seen as feeling negative toward war, a problem in a country that glorified war as a highly positive and purifying phenomenon, as an integral and even central part of the Japanese tradition.

However, Jews were never seen as a fifth column determined to destroy Japan's civilization, and in fact it would have been hard to claim that Jews ever endangered Japan. Since Japan was among the victorious nations in World War I, it was impossible for Japan to blame the Jews for all the world's ailments in the way that Germany blamed them for its defeat in that war. Due to the barriers mentioned above, it was obviously impossible for Jews to play any role in the creative spirit of Japan as they did in Europe. The worst that the Jews' detractors could say about them was that they were purveyors of individualism, a concept that was abhorrent to Japanese nationalists. Some writers blamed the Jews for publicizing Western-style democracy, but it was impossible to accuse them of being a force bent on the disintegration of the Japanese state. Whereas in Europe and even in the United States, Jews were seen as exploiters, usurers, loan sharks, or real estate owners, the Jews in Japan did not engage in the types of pursuits that might lead to such accusations. Some even saw the Jews as bearers of Anglo-American self-centered individualism and materialism, two tendencies in total opposition to the Japanese notion of the supremacy of the collective, the triumph of spirit over matter. Nonetheless, it has to be admitted that in the writings of many anti-Western Japanese thinkers, there is hardly any reference to Jews or Judaism. 
Jews were never seen in Japan as part of the body politic. They were at best part of the foreign community, and therefore they did not arouse the passionate, often hysterical, response they encountered in Nazi Germany. Since they were never seen as an integral part of Japan, and subsequently were not viewed as enemies of that country, Japan's society saw no need to destroy them. The so-called "Jewish Question" was virtually non-existent there: no one wanted or needed to save Japan from the Jews. Unlike the situation in Germany, where Jews were very active in the socialist and communist parties, in the media, in academia, among the judiciary, and at the helm of some of the major corporations in Germany, not to mention the banks, in Japan the Jews were not a major part of public life.

One Japanese thinker who was interested in Judaism was Hiraizumi Kiyoshi (1895-1984), a professor of history at Tokyo University who in 1924 expressed doubts over the manner in which Japanese history was being taught in Japan. He focused on the study of culture and its influence on the spirit of the times, and rejected the trend of objectivity. $\mathrm{He}$ lived briefly in Germany in 1930, and learned much about Judaism from his Jewish friends in Berlin. He was quite impressed with the manner in which the Jews preserved their ancient religion, customs, culture, rites, and language, and sought to understand the role of rites and prayers as preserving the Jewish people even after their expulsion from their ancient homeland by the Romans two thousand years earlier. He thought that the source of Judaism's strength was the Jews' preservation of their spirit and their history, and became convinced that the preservation of tradition is critical for a nation, even one deep in the process of modernization and renewal (ishin). He became a strong advocate of Japanese expansionism in Asia, and in 1937 was one of the founders of a university established in Manchuria by the Kwantung Army. Later, he blamed the defeat of Japan in World War II on the failure of the spirit (seishin). He was one of very few thinkers in Japan who made an effort to understand Jewish history and religion.

The so-called "Jewish Question" in Japan suddenly came into being with the rise of Hitler to power in 1933. From then on, thousands of German Jews sought asylum in any country that was prepared to grant it to them. The Japanese government had not yet adopted any official stand toward Jews, either those already residing in Japan or those wishing to enter it. We have seen that antisemitism was virtually non-existent in Japan in the 1920's, apart from the circulation of tracts translated mainly from Russian. The Jews were never a topic of national concern or debate. 
There were, in fact, a number of intellectuals in Japan who thought that antisemitism lacked any valid foundation. In an academic symposium held in Tokyo in 1928 that dealt with the "Jewish Question," a number of wellknown scholars, among them Uchimura Kanzo (1861-1930) and Hasegawa Nyozekan (1875-1969), came out openly against antisemitism. The conclusions of their position were published in the magazine Heibon in an article which stated that the Protocols of the Elders of Zion was a forgery, that the Zionists had no intention of conquering the world, and that the idea of an international Jewish plot was a fantasy. ${ }^{16}$

Nonetheless, at the same time antisemitic ideas began to seep into social and political discourse in Japan. Antisemitic writers were able to propound these ideas, which often fell into open ears. The deep social and economic frustrations of the late 1920's and early 1930's were placed at the feet of what became known as international Jewry. The severe social crisis that accompanied Japan's rapid process of modernization and industrialization, the growing economic difficulties that followed the world economic crisis, and Japan's growing entanglement in China led Japan on a path of nationalist radicalism, leading to the nurturing of native and unique Japanese values and-above all-belief in the emperor and fear of the West and its values.

The economic crisis would lead Japan to occupy Manchuria in what turned out to be the first shot that eventually led to the Pacific War. Japan also sought allies in Europe. This search soon led her to the arms of Nazi Germany and Fascist Italy, which some Japanese civil and military leaders saw as two other "have not" powers, emasculated by the Treaty of Versailles. Germany, some of these leaders argued, could become a partner to Japan's political and even global ambitions and plans as well as her ideological values. It is obvious that closer ties with Germany would have an impact on Japanese antisemitism, and it is to these changes that we now turn. 